\title{
Evaluation of Commercial Soybean Cultivars for Reaction to Phomopsis Seed Decay
}

Shuxian Li, ${ }^{\dagger}$ United States Department of Agriculture-Agricultural Research Service (USDA-ARS), Crop Genetics Research Unit, Stoneville, MS 38776; Gabe Sciumbato, Mississippi State University, Delta Research and Extension Center, Stoneville, MS 38776; John Rupe, University of Arkansas, Fayetteville, AR 72701; Grover Shannon and Pengyin Chen, Division of Plant Sciences, University of Missouri, Portageville, MO 63873; and Debbie Boykin, USDA-ARS, Stoneville, MS 38776

\begin{abstract}
Phomopsis seed decay (PSD), caused by Phomopsis longicolla (syn. Diaporthe longicolla), is an economically important soybean disease causing poor seed quality. Planting resistant cultivars is one of the most effective means to control PSD. In this study, 16 commercially available maturity groups IV and V soybean cultivars, including two previously identified PSD-resistant and two PSD-susceptible checks, were evaluated for seed infection by $P$. longicolla in inoculated and noninoculated plots, and harvested promptly or with a 2-week delay in harvest. The test was conducted at Stoneville, Mississippi, in 2012 and 2013. Seed

infection by $P$. longicolla ranged from 0.5 to $76 \%$, and seed germination ranged from 18 to $97 \%$. One MG IV cultivar (Morsoy R2 491) and five MG V cultivars (Progeny 5650, Progeny 5706, Asgrow 5606, Asgrow 5831, and Dyna-Gro33C59) had significantly $(P \leq 0.05)$ lower percent seed infected by $P$. longicolla than their respective susceptible checks and other cultivars in the same tests. Information obtained from this study will be useful for soybean growers and breeders for selection of cultivars for planting or breeding and future genetic studies in the development of cultivars with improved resistance to PSD.
\end{abstract}

Phomopsis seed decay (PSD), caused primarily by a seed-borne fungus, Phomopsis longicolla (syn. Diaporthe longicolla (Hobbs) Santos), is one of the most economically important diseases of soybean, Glycine $\max$ (L.) Merrill (Hobbs et al. 1985; Li 2011; Li et al. 2015a; Santos et al. 2011; Sinclair 1993). This disease causes poor seed quality and occurs in most soybean production areas worldwide, especially in the mid-southern region of the United States ( $\mathrm{Li}$ et al. 2011, 2015c; Sinclair 1993). In addition to P. longicolla, there are other important fungal pathogens causing soybean diseases, such as Diaporthe phaseolorum (Cooke \& Ellis) Sacc. (anamorph P. phaseoli (Desm.) Sacc.) including D. phaseolorum var. caulivora K. L. Athow \& R. M. Caldwell, and D. aspalathi E. Jansen, Castl. and Crous (syn. D. phaseolorum var. meridionalis F. A. Fermández), and D. phaseolorum var. sojae (S. G. Lehman) in the DiaporthePhomopsis complex. Although these pathogens may be associated with PSD (Hartman et al. 2015), research has demonstrated that soybean seeds, instead of stems and other soybean tissues, are more susceptible to $P$. longicolla than to other Diaphorthe species (Xue et al. 2007). Differences in aggressiveness on soybean among $P$. longicolla isolates have been found, and isolates from nonlegume hosts infect soybean aggressively (Li et al. 2001, 2010).

Soybean seed infected by $P$. longicolla can be discolored with shriveled and elongated shapes or have cracked seed coats appearing chalky white. However, in some cases, infected soybean seed do not exhibit visible symptoms or signs (Kulik and Sinclair 1999; Sinclair 1993). Symptomless soybean seed with Phomopsis infections could have low seed germination and seedling vigor, and poor stands as seeds with symptoms (Gleason and Ferriss 1985; Sinclair 1993). $P$. longicolla can alter seed composition, decrease oil quality, and cause high frequency of moldy and/or split beans (Hepperly and Sinclair 1978), resulting in poor seed quality. Significant yield loss

${ }^{\dagger}$ Corresponding author: S. Li; E-mail: shuxian.li@ars.usda.gov

Mention of trade names or commercial products in this publication is solely for the purpose of providing specific information and does not imply recommendation or endorsement by the U.S. Department of Agriculture. USDA is an equal opportunity provider and employer.

Accepted for publication 13 August 2017.

C) 2017 The American Phytopathological Society of soybean caused by PSD has been reported, but varied by year and environment (Baird et al. 2001; Wrather et al. 2003; Wrather and Koenning 2009). In 2009, warm and humid environments favored disease development (Balducchi and McGee 1987; Rupe 1990; Rupe and Ferriss 1986; TeKrony et al. 1983) during the late growing season in the southern United States, and PSD caused soybean yield losses over 0.33 million metric tons in 16 southern states (Koenning 2010). However, in 2010 and 2011, there was little infection by P. longicolla in Arkansas, Mississippi, and Missouri because of hot and dry conditions during seed maturation (Li et al. 2015c). High incidence of seed decay has also occurred when plants were deficient in potassium or when infected by Soybean mosaic virus (Koning et al. 2001, 2003).

Several control strategies have been used to manage PSD, including crop rotation with non-soybean host crops, conventional tillage, foliar fungicide treatments (Cross et al. 2012; Jardine 1991; TeKrony et al. 1985; Wrather et al. 2004; Xue et al. 2007), harvesting mature seeds on time, and use of host genetic resistance (Jackson et al. 2005; Pathan et al. 2009; Roy et al. 1994). Use of PSD-resistant soybean cultivars is the most economical and environmentally friendly means to control PSD (Jackson et al. 2005, 2009; Li and Chen 2013; Pathan et al. 2009; Roy et al. 1994; Zimmerman and Minor 1993).

Comprehensive screening of plant introductions from the USDA Germplasm Collection (https://www.ars-grin.gov/npgs/) for resistance to PSD has been reported (Brown et al. 1987; Li et al. 2011, 2015c). However, information about the reaction of commercial soybean cultivars to $P$. longicolla is lacking. We hypothesized that PSD-resistant gene(s) may exist in commercial soybean cultivars, and cultivars with different levels of resistance to PSD could be identified. The objective of this study was to identify soybean cultivars with resistance to PSD and high seed quality by evaluating reactions to $P$. longicolla infection following inoculation and either prompt or delayed harvest at maturity or with a 2-week delay in harvest post-maturity.

\section{Materials and Methods}

Soybean cultivars. Sixteen commercially available soybean cultivars from maturity groups IV and V were selected from the "Cross-Reference Guide for Common Soybean Varieties-2011" that were recommended by the Mississippi Soybean Promotion Board (http://mssoy.org) based on yield performance in Mississippi Soybean Variety Trials at multiple locations. Information about the reaction of those cultivars to Phomopsis seed decay was lacking. Two previously identified PSD resistant checks, SS93-6181 (Pathan et al. 2009) and PI 424324B (Li et al. 
2011), and two susceptible checks, AP 350 (Jackson et al. 2005) and Osage, were also included in this study (Table 1). Osage is a conventional cultivar developed and commonly grown in Arkansas (Chen et al. 2007). Osage also was reported to be resistant to several important diseases in the mid-southern U.S.A., including southern stem canker, sudden death syndrome, Soybean mosaic virus, and frogeye leaf spot (Chen et al. 2007), but appeared to be susceptible to PSD in Mississippi in a preliminary test ( $\mathrm{Li}$, unpublished). All soybean seeds were obtained from Mississippi State University, Delta Research and Extension Center.

Field experiments. Field experiments were conducted at Stoneville, Mississippi, in a Sharkey clay soil (very fine, smectitic, thermictic Chromic Epiaquert) in 2012 and 2013. This field has been used to screen soybean plant introductions for resistance to PSD since 2006. For all experiments, seeds were planted at a rate of 33 seeds $/ \mathrm{m}$ of row, in $2.74 \mathrm{~m}$-long double-row plots with a $0.91-\mathrm{m}$ row spacing. The plot size was $1.82 \mathrm{~m} \times 2.74 \mathrm{~m}$. Each plot of each cultivar was a single replication.

There were separate experiments for each maturity group (MG IV and MG V). Experimental design for each experiment was a splitsplit plot with inoculation treatment (inoculated and noninoculated) as the main plot and harvest date (prompt harvest or a 2-week delay in harvest) as subplot. Cultivars were randomly arranged with four replications as paired plots, one for prompt harvest and one for delayed harvest. All plants (approximately 80 ) in each plot were manually harvested. Pre-emergence herbicides of Gramoxone at 2.33 liters/ha and Dual at 1.8 liters/ha (Syngenta Crop Protection, Greensboro, NC) were applied on the second day after planting. Since that, there was no chemical treatment to the field because experiments involved pathogen inoculation. Weed removal was conducted manually. Planting dates in each year are listed in Table 2.

Inoculations were performed at the R5 growth stage (Fehr and Caviness 1997) each year (Table 2). To promote infection, plants were irrigated two to three times a day following inoculation if there was no rain. Approximately 250 liters of water were applied for each irrigation. Irrigation was conducted with overhead Rain Bird Brass Impact Sprinklers (Model \#25P JDA-C). Sprinklers were connected to a nurse wagon equipped with a Honda engine/pacer poly pump (Bell Inc., Inverness, MS). In the following 6 to 7 weeks (from R5 to R8 growth stages) after inoculation, plots were irrigated two to three times a week if needed.

Inoculum preparation and application. Isolate MSPL 10-6 of $P$. longicolla was used for inoculation in the experiments. This isolate was originally from field-grown soybean plants in Stoneville, MS, and its genome sequence is publicly available ( $\mathrm{Li}$ et al. 2015b). Isolate MSPL 10-6 has also been used in previous studies to identify new sources of resistance to PSD (Li et al. 2011, 2015c). To prepare the inoculum, the isolate was grown at $24^{\circ} \mathrm{C}$ on potato dextrose agar (Difco Laboratories, Detroit, MI) adjusted to $\mathrm{pH} 4.8$ with $25 \%$ lactic acid (APDA) after autoclaving. Inoculum was prepared as previously reported ( $\mathrm{Li}$ et al. 2011, 2015c). Briefly, cultures were induced to sporulate under a fluorescent light output of $300 \mu \mathrm{mol} \mathrm{m} \mathrm{m}^{-2} \mathrm{~s}^{-1}$ with a 12-h photoperiod for 30 to 45 days. Sporulating cultures were flooded with sterile deionized water three times, agitated to dislodge conidiospores, and filtered with four layers of sterile cheesecloth to eliminate the agar. Conidiospore concentrations were adjusted to approximately $1.5 \times 10^{5} / \mathrm{ml}$ with a hemacytometer (Hausser Scientific, Blue Bell, PA). The quality of the inoculum was determined by the colony-forming unit ( $\mathrm{CFU}$ ) of diluted conidiospore suspension containing 100 conidiospores on APDA. Field inoculations were conducted using a battery-operated backpack sprayer Solo Model 416 (Flojet Co., Santa Ana, CA) with a hand-held boom containing a single nozzle with an adjustable orifice at $207 \mathrm{kPa}$. Conidiospore suspension was sprayed directly on the pods and then evenly across the foliage in each plot. Plots were sprayed to runoff ( $\mathrm{Li}$ et al. 2011, 2015c). Approximately $500 \mathrm{ml}$ of conidiospore suspension was applied to each plot.

Seed assays. Prior to planting, 30 seeds of each line provided by Mississippi State University, Delta Research and Extension Center, were assayed for incidence of $P$. longicolla. After manual harvest, 50 randomly chosen seeds (13\% moisture) from each plot (200 seeds

Table 1. A list of soybean cultivars evaluated for resistance to Phomopsis longicolla

\begin{tabular}{lclll}
\hline Cultivar & $\begin{array}{c}\text { Maturity } \\
\text { group }\end{array}$ & $\begin{array}{c}\text { Seed coat } \\
\text { color }\end{array}$ & Seed \\
source & Country \\
\hline Armor ARX 1482 & IV & Yellow & Armor Seed Co. & Missouri Farmers Association \\
Morsoy R2 491 & IV & Yellow & Missouri Farmers Association & U.S.A. \\
Morsoy R2S 480 & IV & Yellow & Pioneer Hibred Seed Co. & U.S.A. \\
Pioneer 94Y90 & IV & Yellow & University of Missouri & U.S.A. \\
SS93-6181y & IV & Yellow & Agripro Seed Co. & U.S.A. \\
AP 350 & IV & Yellow & Monsanto & U.S.A. \\
Asgrow 5606 & V & Yellow & Monsanto & U.S.A. \\
Asgrow 5831 & V & Yellow & Crop Production Services \\
Dyna-Gro 37RY52 & V & Yellow & Erwin Keith & U.S.A. \\
Dyna-Gro 33C59 & V & Yellow & Monsanto & U.S.A. \\
Progeny 4949 & V & Yellow & Monsanto & U.S.A. \\
Progeny 5650 & V & Yellow & Monsanto & U.S.A. \\
Progeny 5706 & V & Yellow & USDA Germplasm Collection \\
Terral 59R16 & V & Green & University of Arkansas \\
PI424324B & V & Yellow & & South Korea \\
Osage & V & & & U.S.A. \\
\hline
\end{tabular}

y Resistant check.

${ }^{\mathrm{z}}$ Susceptible check.

Table 2. Planting, inoculation, and harvest dates for evaluating soybean cultivars for response to Phomopsis longicolla in Stoneville, MS, in 2012 and 2013

\begin{tabular}{|c|c|c|c|c|c|c|c|}
\hline \multirow[b]{3}{*}{ Year } & \multirow[b]{3}{*}{ Planting date } & & & \multicolumn{4}{|c|}{ Harvest dates ${ }^{\mathrm{z}}$} \\
\hline & & \multicolumn{2}{|c|}{ Inoculation dates $^{y}$} & \multicolumn{2}{|c|}{ Maturity group IV } & \multicolumn{2}{|c|}{ Maturity group V } \\
\hline & & Maturity group IV & Maturity group V & Prompt & Delayed & Prompt & Delayed \\
\hline 2012 & 25 April & 19 July, 31 July & 25 July, 8 Aug. & 14 Sep. -21 Sep. & 28 Sep. -5 Oct. & 27 Sep. -10 Oct. & 12 Oct. -25 Oct \\
\hline 2013 & 30 April & 16 July, 30 July & 30 July, 13 Aug. & 16 Sep. -27 Sep. & 30 Sep. -10 Oct. & 18 Oct. & 30 Oct. \\
\hline
\end{tabular}

${ }^{y}$ Two treatments. Soybean plants were either inoculated with spore suspension of $P$. longicolla ( 1 to $1.5 \times 10^{5} / \mathrm{ml}$ ) at the R5 growth stage (inoculated treatment) or sprayed with distilled water (noninoculated treatment).

${ }^{\mathrm{z}}$ Harvests were conducted manually: Prompt (at R8 growth stages) versus delayed harvest (at R8 +2 weeks). 
for each soybean cultivar) were assayed to determine the percent seed infection by $P$. longicolla, percent standard seed germination, and visual seed quality with the methods as previously reported $(\mathrm{Li}$ et al. $2015 \mathrm{c}$ ). Seeds were surface-disinfected in $0.5 \%$ sodium hypochlorite for $3 \mathrm{~min}$, rinsed in sterile distilled water, and then placed on APDA (Li et al. 2011, 2015c). Five seeds were placed on APDA in each $100 \mathrm{~mm} \times 15 \mathrm{~mm}$ Petri dish where one seed was placed in the center and the others were placed equidistant around the outside of the dish, approximately $10 \mathrm{~mm}$ from the side with approximately $30 \mathrm{~mm}$ between seeds. All seed plates were incubated for 4 days at $24^{\circ} \mathrm{C}$. Putative $P$. longicolla colonies and the type strain $\mathrm{TWH}$ P74 (ATCC 60325) were transferred to new APDA plates. Two isolates from each cultivar were single-spore purified for verification. $P$. longicolla was initially identified with a comparison of the type strain using morphological characteristics including conidial type, sporulation, and stromal pattern according to Hobbs et al. (1985). Further identification was confirmed by analysis of the internal transcribed spacer (ITS) regions of rDNA amplified by PCR with primers ITS1, 5'-TCCGTAGGTGAACCTGCGG-3'and ITS4, 5'TCCTCCGCTTATTGATATGC-3' (Li et al. 2015b; White et al. 1990 ), and the translation elongation factor $1-\alpha$ gene (TEF-1 $\alpha$ ) with primers EF1-728F, 5'-CATCGAGAAGTTCGAGAAGG-3', and EF1-986R, 5'-TACTTGAAGGAACCCTTACC-3' (Carbone and Kohn 1999; Li and Hartman 2003). All sequences were analyzed using BLASTn at https://blast.ncbi.nlm.nih.gov/Blast.cgi. Other soybean seed pathogens, such as Alternaria spp., Cercospora spp., and Fusarium spp., have different culture morphology from $P$. longicolla and were identified based on the description in Hartman et al. (2015).

The number of seeds infected with $P$. longicolla was recorded and calculated as percent seed infection. Seed germination of 100 arbitrarily selected seeds from each plot was determined using a standard soybean seed germination protocol (Association of Official Seed Analysts 2001). Visual scoring of seed quality was determined with a scale of 1 to 5 as previously reported (Li et al. 2015c), in which $1=$ excellent (no discolored seed); 2 = good (less than $10 \%$ discolored seed); $3=$ fair (11 to $30 \%$ discolored seed $) ; 4=$ poor $(31$ to $50 \%$ discolored seed); and $5=$ very poor (more than $50 \%$ discolored seed). Seed wrinkling, molding, mottling, and discoloration were the factors in estimating seed quality (Li et al. 2015c).

Weather data of total precipitation, number of rainy days, average maximum temperatures, and maximum relative humidity during the soybean growing season were obtained from the Stoneville, MS, weather station (http://ext.msstate.edu/anr/drec/stations.cgi?defstation=Stoneville).

Table 3. Analysis of variance of Phomopsis seed infection, germination, and visual seed quality of 16 cultivars from inoculated field trials with two harvest times in Stoneville, MS, in 2012 and 2013 ${ }^{\mathrm{r}}$

\begin{tabular}{|c|c|c|c|c|c|c|c|}
\hline \multirow[b]{2}{*}{ Source of variance } & \multirow[b]{2}{*}{ Num DFs } & \multicolumn{2}{|c|}{ PSD $^{\mathbf{t}}$} & \multicolumn{2}{|c|}{ Germination $^{\mathrm{u}}$} & \multicolumn{2}{|c|}{ Visual score $^{\mathrm{v}}$} \\
\hline & & $F$ & $P \geq F$ & $F$ & $P \geq F$ & $F$ & $P \geq F$ \\
\hline \multicolumn{8}{|l|}{ Fixed effects } \\
\hline \multicolumn{8}{|l|}{ Maturity group IV } \\
\hline $\mathrm{INOC}^{\mathrm{w}}$ & 1 & 25.77 & $<0.0001$ & 41.76 & $<0.0001$ & 0.00 & 0.9857 \\
\hline $\mathrm{CV}^{\mathrm{x}}$ & 5 & 3.96 & 0.0022 & 7.57 & $<0.0001$ & 1.53 & 0.1844 \\
\hline $\mathrm{INOC} \times \mathrm{CV}$ & 5 & 0.63 & 0.6743 & 2.28 & 0.0503 & 2.27 & 0.0511 \\
\hline HAR $^{y}$ & 1 & 164.08 & $<0.0001$ & 41.15 & $<0.0001$ & 3.97 & 0.0485 \\
\hline INOC $\times$ HAR & 1 & 0.04 & 0.8384 & 10.03 & 0.0019 & 0.00 & 0.9971 \\
\hline $\mathrm{CV} \times \mathrm{HAR}$ & 5 & 4.24 & 0.0013 & 2.98 & 0.014 & 1.53 & 0.1848 \\
\hline $\mathrm{INOC} \times \mathrm{CV} \times \mathrm{HAR}$ & 5 & 0.17 & 0.9716 & 0.15 & 0.9791 & 2.27 & 0.0514 \\
\hline $\mathrm{YR}^{\mathrm{z}}$ & 1 & 133.49 & $<0.0001$ & 9.02 & 0.011 & 0.00 & 0.9986 \\
\hline $\mathrm{INOC} \times \mathrm{YR}$ & 1 & 10.04 & 0.0019 & 27.68 & 0.0002 & 3.81 & 0.0742 \\
\hline $\mathrm{CV} \times \mathrm{YR}$ & 5 & 2.33 & 0.046 & 3.12 & 0.0107 & 2.28 & 0.0507 \\
\hline $\mathrm{INOC} \times \mathrm{CV} \times \mathrm{YR}$ & 5 & 0.07 & 0.9968 & 0.52 & 0.764 & 1.54 & 0.1825 \\
\hline $\mathrm{HAR} \times \mathrm{YR}$ & 1 & 73.59 & $<0.0001$ & 2.96 & 0.0878 & 0.00 & 0.9991 \\
\hline $\mathrm{INOC} \times \mathrm{HAR} \times \mathrm{YR}$ & 1 & 0.06 & 0.8146 & 11.15 & 0.0011 & 3.89 & 0.0507 \\
\hline $\mathrm{CV} \times \mathrm{HAR} \times \mathrm{YR}$ & 5 & 2.74 & 0.0218 & 1.86 & 0.1056 & 2.28 & 0.0507 \\
\hline $\mathrm{INOC} \times \mathrm{CV} \times \mathrm{HAR} \times \mathrm{YR}$ & 5 & 1.51 & 0.1892 & 0.70 & 0.6249 & 1.53 & 0.1836 \\
\hline \multicolumn{8}{|l|}{ Maturity group V } \\
\hline INOC & 1 & 22.47 & $<0.0001$ & 3.36 & 0.0680 & 1.31 & 0.2629 \\
\hline $\mathrm{CV}$ & 9 & 11.76 & $<0.0001$ & 2.76 & 0.0043 & 1.96 & 0.0612 \\
\hline $\mathrm{INOC} \times \mathrm{CV}$ & 9 & 0.93 & 0.5043 & 1.75 & 0.0778 & 1.97 & 0.0603 \\
\hline HAR & 1 & 13.67 & 0.0003 & 2.76 & 0.0979 & 0.00 & 0.9994 \\
\hline INOC $\times$ HAR & 1 & 10.01 & 0.0018 & 3.06 & 0.0813 & 0.00 & 0.9935 \\
\hline $\mathrm{CV} \times \mathrm{HAR}$ & 9 & 7.5 & $<0.0001$ & 1.80 & 0.0692 & 0.00 & 1.0000 \\
\hline $\mathrm{INOC} \times \mathrm{CV} \times \mathrm{HAR}$ & 9 & 1.64 & 0.1058 & 1.96 & 0.0442 & 0.00 & 1.0000 \\
\hline YR & 1 & 372.88 & $<0.0001$ & 0.27 & 0.6030 & 2.36 & 0.1587 \\
\hline $\mathrm{INOC} \times \mathrm{YR}$ & 1 & 6.01 & 0.0152 & 2.22 & 0.1376 & 2.40 & 0.1556 \\
\hline $\mathrm{CV} \times \mathrm{YR}$ & 9 & 5.6 & $<0.0001$ & 1.82 & 0.0654 & 5.65 & $<0.0001$ \\
\hline $\mathrm{INOC} \times \mathrm{CV} \times \mathrm{YR}$ & 9 & 0.85 & 0.5699 & 1.85 & 0.0602 & 5.66 & $<0.0001$ \\
\hline $\mathrm{HAR} \times \mathrm{YR}$ & 1 & 18.72 & $<0.0001$ & 2.76 & 0.0979 & 0.00 & 0.9994 \\
\hline $\mathrm{INOC} \times \mathrm{HAR} \times \mathrm{YR}$ & 1 & 0.7 & 0.4036 & 3.06 & 0.0813 & 0.00 & 0.9935 \\
\hline $\mathrm{CV} \times \mathrm{HAR} \times \mathrm{YR}$ & 9 & 5.9 & $<0.0001$ & 1.80 & 0.0692 & 0.00 & 1.0000 \\
\hline $\mathrm{INOC} \times \mathrm{CV} \times \mathrm{HAR} \times \mathrm{YR}$ & 9 & 0.67 & 0.7340 & 1.96 & 0.0442 & 0.00 & 1.0000 \\
\hline \multirow{2}{*}{\multicolumn{8}{|c|}{ r Analysis of variance (ANOVA) was performed using generalized linear mixed model (PROC GLMMIX) of SAS. }} \\
\hline & & & & & & & \\
\hline \multirow{3}{*}{\multicolumn{8}{|c|}{$\begin{array}{l}\text { Phomopsis seed infection was calculated as percent seed infection by Phomopsis longicolla from the seed plating assays. } \\
\text { u Percent seed germination based on tests of } 100 \text { seeds from each of four replications. }\end{array}$}} \\
\hline & & & & & & & \\
\hline \multicolumn{6}{|c|}{ Visual quality of seeds were assessed using a scale of 1 to 5.} & & \\
\hline \multicolumn{8}{|c|}{$\begin{array}{l}\text { Soybean plants were inoculated with a spore suspension of } P \text {. longicolla }\left(1 \text { to } 1.5 \times 10^{5} / \mathrm{ml}\right) \text { at the } \mathrm{R} 5 \text { growth stage. Noninoculated plants were sprayed with } \\
\text { distilled water. }\end{array}$} \\
\hline $\begin{array}{l}\text { distilled water. } \\
\text { Cultivar. }\end{array}$ & & & & & & & \\
\hline y Tw h b tim & & & & & & & \\
\hline
\end{tabular}


Data analyses. Statistical analysis of data were performed using the generalized linear mixed procedure (PROC GLMMIX) of SAS (version 9.4, SAS Institute, Cary, NC) with a negative binomial distribution and a log link function specified for Phomopsis seed infection (Littell et al. 2006). Seed germination and seed quality scores were calculated as the mean percentage of each cultivar. Data were combined across the two years to test if there were interactions between cultivar and year when "year" was the fixed effect, and to

Table 4. Percent seed infection by Phomopsis longicolla of six maturity group IV soybean cultivars in replicated, inoculated field tests with prompt and delayed harvests in Stoneville, MS, in 2012 and 2013

\begin{tabular}{|c|c|c|c|c|c|c|}
\hline \multirow[b]{3}{*}{ Cultivar } & \multirow[b]{3}{*}{ Year } & \multirow[b]{3}{*}{ Maturity group } & \multicolumn{4}{|c|}{ Phomopsis $(\%)^{\mathrm{s}}$} \\
\hline & & & \multicolumn{2}{|c|}{ Prompt harvest $^{t}$} & \multicolumn{2}{|c|}{ Delayed harvest ${ }^{\mathbf{u}}$} \\
\hline & & & $\operatorname{Non}^{v}$ & Inocw $^{w}$ & Non & Inoc \\
\hline AP $350^{x}$ & 2012 & IV & $15.0 \mathrm{ab}^{\mathrm{y}}$ & $26.0 \mathrm{a}$ & $48.0 \mathrm{ab}$ & $43.0 \mathrm{abc}$ \\
\hline Armor ARX 1482 & 2012 & IV & $19.0 \mathrm{ab}$ & $18.0 \mathrm{abc}$ & $42.0 \mathrm{abc}$ & $49.0 \mathrm{ab}$ \\
\hline Morsoy R2 491 & 2012 & IV & $11.0 \mathrm{~b}$ & $12.0 \mathrm{bc}$ & $28.0 \mathrm{c}$ & $31.0 \mathrm{bc}$ \\
\hline Morsoy R2s 480 & 2012 & IV & $11.0 \mathrm{~b}$ & $10.0 \mathrm{c}$ & $60.0 \mathrm{a}$ & $64.0 \mathrm{a}$ \\
\hline Pioneer 94Y90 & 2012 & IV & $20.0 \mathrm{a}$ & $23.0 \mathrm{ab}$ & $33.0 \mathrm{bc}$ & $45.0 \mathrm{ab}$ \\
\hline SS93-6181z & 2012 & IV & $12.0 \mathrm{~b}$ & $13.0 \mathrm{bc}$ & $44.0 \mathrm{abc}$ & $41.0 \mathrm{bc}$ \\
\hline Mean & & & 14.7 & 17.0 & 42.5 & 45.5 \\
\hline AP 350 & 2013 & IV & $1.6 \mathrm{a}$ & $2.4 \mathrm{ab}$ & $0.8 \mathrm{a}$ & $8.0 \mathrm{a}$ \\
\hline Armor ARX 1482 & 2013 & IV & $1.5 \mathrm{a}$ & $3.2 \mathrm{ab}$ & $1.2 \mathrm{a}$ & $3.7 \mathrm{~b}$ \\
\hline Morsoy R2 491 & 2013 & IV & $1.4 \mathrm{a}$ & $2.1 \mathrm{ab}$ & $0.5 \mathrm{a}$ & $4.0 \mathrm{~b}$ \\
\hline Morsoy R2s 480 & 2013 & IV & $1.4 \mathrm{a}$ & $1.8 \mathrm{~b}$ & $1.8 \mathrm{a}$ & $4.2 \mathrm{~b}$ \\
\hline Pioneer 94Y90 & 2013 & IV & $1.6 \mathrm{a}$ & $5.2 \mathrm{a}$ & $1.8 \mathrm{a}$ & $4.2 \mathrm{~b}$ \\
\hline SS93-6181 & 2013 & IV & $1.4 \mathrm{a}$ & $1.9 \mathrm{~b}$ & $1.4 \mathrm{a}$ & $4.3 \mathrm{~b}$ \\
\hline Mean & & & 1.5 & 2.8 & 1.3 & 4.7 \\
\hline
\end{tabular}

${ }^{s}$ Percent seed infection by $P$. longicolla from plating assays analyzed with a negative binomial distribution and log link function.

${ }^{t}$ Harvested promptly at R8 growth stage.

u Delayed harvest 2 weeks after R8.

${ }^{v}$ Noninoculated treatment.

${ }^{\mathrm{w}}$ Inoculated treatment.

x Susceptible check.

y Means followed by the same letter within a column are not significantly different as determined by the least significant difference test at $P \leq 0.05$.

${ }^{\mathrm{z}}$ Resistant check.

Table 5. Percent seed infection by Phomopsis longicolla of 10 maturity group V soybean cultivars in replicated, inoculated field tests with prompt and delayed harvests in Stoneville, MS, in 2012 and 2013

\begin{tabular}{|c|c|c|c|c|c|c|}
\hline \multirow[b]{3}{*}{ Cultivar } & \multirow[b]{3}{*}{ Year } & \multirow[b]{3}{*}{ Maturity group } & \multicolumn{4}{|c|}{ Phomopsis $(\%)^{\mathrm{s}}$} \\
\hline & & & \multicolumn{2}{|c|}{ Prompt harvest ${ }^{\mathbf{t}}$} & \multicolumn{2}{|c|}{ Delayed harvestu } \\
\hline & & & Nonv & Inocw $^{w}$ & Non & Inoc \\
\hline Asgrow 5606 & 2012 & $\mathrm{~V}$ & $6.0 \mathrm{~cd}^{\mathrm{x}}$ & $6.0 \mathrm{c}$ & $14.7 \mathrm{bc}$ & $20.0 \mathrm{~b}$ \\
\hline Asgrow 5831 & 2012 & $\mathrm{~V}$ & $6.0 \mathrm{~cd}$ & $19.0 \mathrm{~b}$ & $10.0 \mathrm{~cd}$ & $14.0 \mathrm{bc}$ \\
\hline Dyna-Gro 37RY52 & 2012 & $\mathrm{~V}$ & $11.0 \mathrm{ab}$ & $12.0 \mathrm{~b}$ & $34.0 \mathrm{a}$ & $59.0 \mathrm{a}$ \\
\hline Dyna-Gro 33C59 & 2012 & $\mathrm{~V}$ & $9.0 \mathrm{bc}$ & $18.0 \mathrm{~b}$ & $11.0 \mathrm{bcd}$ & $23.0 \mathrm{~b}$ \\
\hline Progeny 4949 & 2012 & $\mathrm{~V}$ & $11.0 \mathrm{ab}$ & $20.0 \mathrm{ab}$ & $25.0 \mathrm{ab}$ & $47.0 \mathrm{ab}$ \\
\hline Progeny 5650 & 2012 & $\mathrm{~V}$ & $6.0 \mathrm{~d}$ & $7.0 \mathrm{bc}$ & $6.0 \mathrm{~d}$ & $13.0 \mathrm{bc}$ \\
\hline Progeny 5706 & 2012 & $\mathrm{~V}$ & $5.0 \mathrm{~d}$ & $9.0 \mathrm{bc}$ & $14.0 \mathrm{bc}$ & $14.0 \mathrm{bc}$ \\
\hline Terral 59R16 & 2012 & $\mathrm{~V}$ & $22.0 \mathrm{a}$ & $22.0 \mathrm{a}$ & $24.0 \mathrm{abc}$ & $53.0 \mathrm{a}$ \\
\hline PI 424324B & 2012 & $\mathrm{~V}$ & $6.0 \mathrm{~d}$ & $6.0 \mathrm{c}$ & $6.0 \mathrm{~d}$ & $5.0 \mathrm{c}$ \\
\hline Osage $^{z}$ & 2012 & $\mathrm{~V}$ & $12.0 \mathrm{ab}$ & $13.0 \mathrm{~b}$ & $36.0 \mathrm{a}$ & $76.0 \mathrm{a}$ \\
\hline Mean & & & 10.3 & 13.7 & 17.2 & 31.9 \\
\hline Asgrow 5606 & 2013 & V & $2.6 \mathrm{bcd}$ & $4.0 \mathrm{abc}$ & $2.6 \mathrm{a}$ & $1.8 \mathrm{~d}$ \\
\hline Asgrow 5831 & 2013 & $\mathrm{~V}$ & $2.2 \mathrm{bcd}$ & $5.0 \mathrm{ab}$ & $0.5 \mathrm{bc}$ & $6.5 \mathrm{ab}$ \\
\hline Dyna-Gro 37RY52 & 2013 & $\mathrm{~V}$ & $2.2 \mathrm{bcd}$ & 2.2.bcde & $3.3 \mathrm{a}$ & $5.2 \mathrm{abc}$ \\
\hline Dyna-Gro 33C59 & 2013 & V & $4.6 \mathrm{ab}$ & $6.8 \mathrm{a}$ & $1.0 \mathrm{abc}$ & $4.8 \mathrm{abc}$ \\
\hline Progeny 4949 & 2013 & $\mathrm{~V}$ & $5.4 \mathrm{a}$ & $3.2 \mathrm{bcd}$ & $2.2 \mathrm{ab}$ & $7.0 \mathrm{a}$ \\
\hline Progeny 5650 & 2013 & $\mathrm{~V}$ & 1.4 cde & $1.0 \mathrm{de}$ & $1.8 \mathrm{abc}$ & $1.6 \mathrm{de}$ \\
\hline Progeny 5706 & 2013 & $\mathrm{~V}$ & $0.8 \mathrm{de}$ & $2.0 \mathrm{cde}$ & $1.0 \mathrm{abc}$ & $2.7 \mathrm{~cd}$ \\
\hline Terral 59R16 & 2013 & $\mathrm{~V}$ & $3.2 \mathrm{abc}$ & $3.2 \mathrm{bcd}$ & $2.0 \mathrm{abc}$ & $3.3 \mathrm{bcd}$ \\
\hline PI 424324B & 2013 & $\mathrm{~V}$ & $0.0 \mathrm{e}$ & $0.6 \mathrm{e}$ & $0.0 \mathrm{c}$ & $0.0 \mathrm{e}$ \\
\hline Osage & 2013 & $\mathrm{~V}$ & $6.6 \mathrm{a}$ & $3.4 \mathrm{abc}$ & $2.6 \mathrm{ab}$ & $6.6 \mathrm{ab}$ \\
\hline Mean & & & 2.9 & 3.2 & 1.7 & 4.0 \\
\hline
\end{tabular}

s Percent seed infection by $P$. longicolla from plating assays analyzed with a negative binomial distribution and log link function.

t Harvested promptly at R8 growth stage.

u Delayed harvest 2 weeks after R8.

v Noninoculated treatment.

${ }^{\mathrm{w}}$ Inoculated treatment.

${ }^{x}$ Means followed by the same letter within a column are not significantly different as determined by the least significant difference test at $P \leq 0.05$.

y Resistant check.

${ }^{\mathrm{z}}$ Susceptible check 
compare cultivars within a year, in which year was the random effect and the cultivar was the fixed effect. The cultivars were compared with Fisher's least significant difference (LSD) at $P \leq 0.05$. The PROC CORR procedure of SAS was used to compute Pearson's correlation coefficients between percent seed infected by $P$. longicolla and germination rate, and between percent seed infection and visual seed quality.

\section{Results}

Maximum air temperatures during the soybean growing season in 2012 averaged $29.8^{\circ} \mathrm{C}$ and ranged from 21.5 to $33.9^{\circ} \mathrm{C}$. In 2013 , air temperatures averaged $28.8^{\circ} \mathrm{C}$ and ranged from 22.3 to $33.8^{\circ} \mathrm{C}$. In August, most of plants were at the R5 or R6 growth stage. The average daily maximum air temperature for August in both 2012 and 2013 was similar at 33.9 and $33.8^{\circ} \mathrm{C}$, respectively, which was higher than $24^{\circ} \mathrm{C}$, the optimal temperature for PSD. In 2012, total precipitation during June, July, and August was 162, 116, and $169 \mathrm{~mm}$, respectively, while in 2013, total precipitation during those months was 93,49 , and $51 \mathrm{~mm}$, respectively.

Results from seed assays prior to planting indicated that soybean cultivars selected for planting were generally of good quality. Seeds obtained for our tests were free of $P$. longicolla. However, the PSDcausing pathogen was found in seeds harvested from the field experiments. All putative $P$. longicolla isolates obtained from seed plating assays had typical morphology similar to the type strain TWH P74 (ATCC 60325), although there were slight differences in stromal patterns. DNA sequences of 16 selected isolates were identical at the ITS region (accession MF134860) and the TEF-1 $\alpha$ gene (MF189565). These had 99 to $100 \%$ identity with many reported sequences of P. longicolla strains in GenBank, such as isolate FAU657 (KJ590727) and type strain TWH P74 (NR_144924) at the ITS regions, and isolate FAU657 (590766), isolate 600 (AF398896), and ER 1678 (HQ445912) in $T E F-1 \alpha$ gene. However, they were only $84 \%$ similar with $P$. sojae (syn. D. phaseolorum var. sojae) isolates, such as FAU604 (KJ590759), PS/KR (JF461471), and FAU499 (KJ590760). Other seed-borne pathogens, such as Cercospora spp., which produces purple coloration on seed coat and APDA, and Alternaria spp., which has an inverted club shape conidia, were easily identified. Isolation frequency of Cercospora spp. ranged from 0 to $24 \%$, Fusarium spp. were from 0 to $30 \%$, while Alternaria spp. were rarely isolated.
Analysis of variance of Phomopsis seed infection of the experiments involving genotypes of MG IV and MG V indicated that there were significant differences $(P \leq 0.05)$ in cultivars $(\mathrm{CV})$, inoculation (INOC) treatments, harvest time (HAR), and years (YR). There also were interactions of $\mathrm{CV} \times \mathrm{HAR}, \mathrm{INOC} \times \mathrm{YR}, \mathrm{CV} \times \mathrm{YR}, \mathrm{HAR} \times \mathrm{YR}$, and $\mathrm{CV} \times \mathrm{HAR} \times \mathrm{YR}$ (Table 3 ). Mean percentage infected seeds for maturity groups (MGs) IV and V cultivars are shown in Table 4 and Table 5, respectively. Cultivars Morsoy R2S 480 (MG IV) and Progeny 4949 (MG V) had low Phomopsis seed infection when harvested on time but were susceptible to PSD with delayed harvest (Tables 4 and 5). The MG IV cultivar Morsoy R2 491 had significantly ( $P \leq$ $0.05)$ lower percent seed infected by $P$. longicolla than the susceptible check and all other cultivars. Although none of the MG V cultivars had significantly lower percent seed infected by $P$. longicolla than their respective resistant check PI 424324B, five cultivars (Progeny 5650, Progeny 5706, Asgrow 5606, Asgrow 5831, and DynaGro33C59) had significantly lower Phomopsis seed infection than the susceptible group V cultivar Osage.

Effects of harvest time and year on $P$. longicolla seed infection with the combination of inoculation treatments are shown in Table 6. In most cases, $P$. longicolla infection was higher in plots with delayed harvest than those with prompt harvest. For example, susceptible cultivar AP 350 had $20.5 \%$ infection if harvested on time and $45.5 \%$ infection with delayed harvest in 2012. However, resistant PI 424324B had the same low percentages of Phomopsis seed infection in both harvest schemes in 2012 (Table 6).

There were differences in seed germination and visual scores of seed quality among cultivars (Table 7). For example, in 2012, PSD-resistant cultivar Morsoy R2 491 had higher seed germination of 96 and $87 \%$ in the noninoculated and inoculated treatments, respectively, when harvested on time. However, susceptible cultivar AP 350 had seed germination of 79 and $69 \%$ in the noninoculated and inoculated treatments, respectively. In general, inoculation treatments reduced seed germination in most cultivars. For example, in 2013, cultivar Armor ARX 1482 had $91 \%$ seed germination in the noninoculated trial but had only $76 \%$ seed germination in the inoculated trial when harvested on time. In 2013, Asgrow 5606 had $80 \%$ germination in the noninoculated trial but had only $59 \%$ seed germination in the inoculated trial with prompt harvest (Table 7). However, inoculation treatment did not reduce the percentage of seed germination in some cultivars, such as Dyna-

Table 6. Effect of harvest time and year in replicated field tests in Stoneville, MS, in 2012 and 2013 on percent seed infection by Phomopsis longicollat

\begin{tabular}{|c|c|c|c|c|c|c|c|}
\hline \multirow[b]{2}{*}{ Cultivar } & \multirow[b]{2}{*}{ Maturity group } & \multicolumn{3}{|c|}{2012 harvest } & \multicolumn{3}{|c|}{2013 harvest } \\
\hline & & Prompt $^{\mathbf{u}}$ & Delayed $^{\mathbf{v}}$ & $P^{\mathrm{w}}$ & Prompt & Delayed & $P$ \\
\hline AP $350^{x}$ & IV & $20.5 a^{y}$ & $45.5 \mathrm{~b}$ & 0.0055 & $2.0 \mathrm{ab}$ & $4.4 \mathrm{a}$ & 0.0007 \\
\hline Armor ADX 1482 & IV & $19.5 \mathrm{abc}$ & $45.5 \mathrm{~b}$ & 0.0049 & $2.4 \mathrm{ab}$ & $2.5 \mathrm{~b}$ & 0.1340 \\
\hline Morsoy R2 491 & IV & $11.5 \mathrm{bc}$ & $29.5 \mathrm{c}$ & 0.0264 & $1.8 \mathrm{~b}$ & $2.3 \mathrm{~b}$ & 0.1151 \\
\hline Morsoy R2S 480 & IV & $10.5 \mathrm{c}$ & $62.0 \mathrm{a}$ & $<0.0001$ & $1.6 \mathrm{~b}$ & $3.0 \mathrm{ab}$ & 0.0036 \\
\hline Pioneer 94Y90 & IV & $21.5 \mathrm{a}$ & $39.0 \mathrm{bc}$ & 0.0310 & $3.4 \mathrm{a}$ & $3.0 \mathrm{ab}$ & 0.2229 \\
\hline SS93-6181z & IV & $12.5 \mathrm{bc}$ & $42.5 \mathrm{~b}$ & 0.0004 & $1.7 \mathrm{ab}$ & $2.9 \mathrm{ab}$ & 0.0117 \\
\hline Mean & & 15.8 & 44.0 & & 2.1 & 3.0 & \\
\hline Asgrow 5606 & $\mathrm{~V}$ & $6.0 \mathrm{~d}$ & $17.4 \mathrm{c}$ & 0.0062 & $2.2 \mathrm{~b}$ & $3.3 \mathrm{bcd}$ & 0.3343 \\
\hline Asgrow 5831 & $\mathrm{~V}$ & $12.5 \mathrm{c}$ & $12.0 \mathrm{c}$ & 0.8550 & $3.5 \mathrm{ab}$ & $3.6 \mathrm{bc}$ & 0.5467 \\
\hline Dyna-Gro37RY52 & $\mathrm{V}$ & $11.5 \mathrm{c}$ & $46.5 \mathrm{ab}$ & $<0.0001$ & $4.2 \mathrm{a}$ & $2.2 \mathrm{cdef}$ & 0.0532 \\
\hline Dyna-Gro 33C59 & $\mathrm{V}$ & $13.5 \mathrm{c}$ & $17.0 \mathrm{c}$ & 0.3736 & $2.9 \mathrm{ab}$ & $5.7 \mathrm{a}$ & 0.0125 \\
\hline Progeny 4949 & $\mathrm{~V}$ & $17.0 \mathrm{~b}$ & $36.0 \mathrm{~b}$ & 0.0022 & $4.6 \mathrm{a}$ & $4.3 \mathrm{ab}$ & 0.9830 \\
\hline Progeny 5650 & $\mathrm{~V}$ & $6.5 \mathrm{~cd}$ & $9.5 .0 \mathrm{c}$ & 0.4083 & $1.7 \mathrm{bc}$ & $1.2 \mathrm{ef}$ & 0.4085 \\
\hline Progeny 5706 & $\mathrm{~V}$ & $7.0 \mathrm{~cd}$ & $14.0 \mathrm{c}$ & 0.1338 & $1.8 \mathrm{bc}$ & $1.4 \mathrm{def}$ & 0.6305 \\
\hline Terral 59R16 & $\mathrm{V}$ & $22.0 \mathrm{~b}$ & $38.5 \mathrm{~b}$ & 0.0434 & $2.6 \mathrm{ab}$ & 3.2 bcde & 0.5289 \\
\hline PI $424324 B^{z}$ & V & $6.0 \mathrm{~d}$ & $5.5 \mathrm{c}$ & 0.9750 & $0.0 \mathrm{c}$ & $0.3 \mathrm{f}$ & 0.5845 \\
\hline Osage $^{\mathrm{x}}$ & V & $12.5 \mathrm{c}$ & $56.0 \mathrm{a}$ & $<0.0001$ & $4.6 \mathrm{a}$ & $5.0 \mathrm{ab}$ & 0.5371 \\
\hline Mean & & 12.0 & 24.5 & & 2.8 & 3.0 & \\
\hline
\end{tabular}

${ }^{\mathrm{t}}$ Percent seed infection by $P$. longicolla from plating assays analyzed with a negative binomial distribution and log link function.

u Harvested promptly at R8 growth stage.

${ }^{v}$ Delayed harvest 2 weeks after R8.

${ }^{w}$ Probability value for test of significance.

${ }^{x}$ Susceptible check.

y Means followed by the same letter within a column are not significantly different by the least significant difference test at $P \leq 0.05$.

${ }^{\mathrm{z}}$ Resistant check. 
Gro37RY52 and Dyna-Gro 33C59 in the on-time harvest trials in 2012 (Table 7). In general, percent seed infected by $P$. longicolla was negatively correlated with germination rate, but positively correlated with visual seed quality in delayed harvest of MGVI with inoculated treatment and overall harvest time in the inoculated trial of MG V (Table 8). None of the noninoculated trials had significant correlations between percent seed infected by $P$. longicolla and visual seed quality scores.

\section{Discussion}

Environmental conditions have been reported to play an important role in the development of PSD (Gleason and Ferriss 1985; Rupe
1990; Spilker et al. 1981). The favorable environments for PSD, such as warm and humid conditions during the late season from beginning pod fill through harvest, promote the colonization of $P$. longicolla, causing high levels of seed infection.

In the southern United States, the "early soybean production system (ESPS)" is very popular (Heatherly 1999), where early maturing cultivars are planted in late March through April, and mature in August to early September. This system allows the crop to take advantage of plentiful spring and early summer rains to increase chances to avoiding late-season drought, leading to increased yields (Heatherly 1999). However, environments in August are usually hot and humid, which could cause severe PSD and poor seed germination in the

Table 7. Percent seed germination of soybean cultivars and visual seed quality in replicated field tests in Stoneville, MS, in 2012 and 2013

\begin{tabular}{|c|c|c|c|c|c|c|c|c|c|}
\hline \multirow[b]{4}{*}{ Cultivar } & \multirow[b]{4}{*}{ Year } & \multicolumn{8}{|c|}{ Harvest } \\
\hline & & \multicolumn{4}{|c|}{ Prompt $^{r}$} & \multicolumn{4}{|c|}{ Delayed $^{s}$} \\
\hline & & \multicolumn{2}{|c|}{$\mathbf{G M}^{\mathbf{t}}$} & \multicolumn{2}{|c|}{$\mathbf{V Q}^{\mathbf{u}}$} & \multicolumn{2}{|c|}{ GM } & \multicolumn{2}{|c|}{ VQ } \\
\hline & & Nonv & Inoc $^{w}$ & Non & Inoc & Non & Inoc & Non & $\overline{\text { Inoc }}$ \\
\hline \multicolumn{10}{|l|}{ Maturity group IV } \\
\hline Armor ARX 1482 & 2012 & 78.8 & 73.0 & 2.1 & 2.4 & 75.5 & 54.3 & 2.4 & 2.5 \\
\hline Morsoy R2 491 & 2012 & 95.5 & 86.8 & 2.1 & 2.0 & 86.5 & 77.8 & 2.3 & 2.3 \\
\hline Morsoy R2s 480 & 2012 & 87.3 & 82.8 & 2.1 & 2.0 & 61.0 & 30.0 & 2.1 & 2.4 \\
\hline Pioneer 94Y90 & 2012 & 83.3 & 63.5 & 2.3 & 2.1 & 75.0 & 61.8 & 3.0 & 3.0 \\
\hline SS93-6181 & 2012 & 83.0 & 84.8 & 2.0 & 1.8 & 81.8 & 63.0 & 2.8 & 2.8 \\
\hline AP $350^{y}$ & 2012 & 79.0 & 61.3 & 2.5 & 2.1 & 52.3 & 40.3 & 3.1 & 3.5 \\
\hline Mean & & 84.5 & 75.3 & 2.2 & 2.1 & 72.0 & 54.5 & 2.6 & 2.7 \\
\hline $\operatorname{LSD}^{\mathrm{z}}$ & & 8.5 & 24.5 & 0.4 & 0.4 & 21.1 & 13.9 & 0.7 & 0.7 \\
\hline Armor ARX 1482 & 2013 & 90.7 & 76.3 & 1.6 & 1.9 & 50.7 & 44.8 & 2.6 & 3.6 \\
\hline Morsoy R2 491 & 2013 & 87.3 & 81.4 & 1.9 & 2.0 & 62.4 & 50.3 & 2.3 & 2.9 \\
\hline Morsoy R2s 480 & 2013 & 91.3 & 83.3 & 1.6 & 2.0 & 34.5 & 28.7 & 2.3 & 3.0 \\
\hline Pioneer 94Y90 & 2013 & 82.0 & 79.0 & 1.6 & 2.0 & 33.2 & 46.8 & 2.6 & 2.8 \\
\hline SS93-6181 & 2013 & 82.7 & 70.5 & 1.3 & 2.1 & 41.8 & 18.3 & 3.0 & 3.6 \\
\hline AP 350 & 2013 & 85.2 & 69.0 & 1.4 & 2.0 & 49.3 & 18.0 & 2.4 & 3.4 \\
\hline Mean & & 86.5 & 76.6 & 1.6 & 2.0 & 45.3 & 34.5 & 2.5 & 3.2 \\
\hline LSD & & 22.3 & 29.0 & 0.7 & 0.7 & 30.5 & 25.1 & 0.7 & 0.9 \\
\hline \multicolumn{10}{|l|}{ Maturity group V } \\
\hline Asgrow 5606 & 2012 & 94.3 & 92.8 & 2.1 & 1.5 & 96.8 & 87.3 & 2.5 & 1.6 \\
\hline Asgrow 5831 & 2012 & 95.3 & 94.0 & 2.0 & 1.5 & 94.8 & 95.0 & 2.3 & 1.8 \\
\hline Dyna-Gro 37RY52 & 2012 & 94.0 & 96.0 & 1.8 & 1.3 & 76.5 & 74.5 & 2.0 & 1.9 \\
\hline Dyna-Gro 33C59 & 2012 & 93.3 & 94.8 & 1.9 & 1.5 & 94.0 & 92.5 & 1.9 & 1.8 \\
\hline Progeny 4949 & 2012 & 92.3 & 86.8 & 2.6 & 2.1 & 71.8 & 58.8 & 3.8 & 2.9 \\
\hline Progeny 5650 & 2012 & 93.5 & 89.8 & 1.8 & 2.3 & 92.3 & 87.8 & 2.1 & 2.0 \\
\hline Progeny 5706 & 2012 & 96.0 & 91.0 & 2.1 & 1.9 & 94.0 & 95.0 & 2.1 & 2.1 \\
\hline Terral 59R16 & 2012 & 91.0 & 87.3 & 2.4 & 1.8 & 77.3 & 70.8 & 2.6 & 2.4 \\
\hline PI $424324 B^{x}$ & 2012 & 97.0 & 92.8 & 1.3 & 1.6 & 96.5 & 97.8 & 1.5 & 1.5 \\
\hline Osage $^{y}$ & 2012 & 93.3 & 95.0 & 1.6 & 1.6 & 80.8 & 75.5 & 1.8 & 2.0 \\
\hline Mean & & 94.0 & 92.0 & 2.0 & 1.7 & 87.5 & 83.5 & 2.3 & 2.0 \\
\hline LSD & & 5.7 & 10.8 & 0.6 & 0.6 & 12.5 & 13.4 & 0.7 & 0.6 \\
\hline Asgrow 5606 & 2013 & 80.3 & 59.0 & 2.1 & 2.3 & 59.0 & 77.0 & 1.8 & 2.0 \\
\hline Asgrow 5831 & 2013 & 70.0 & 60.5 & 1.8 & 2.5 & 60.5 & 74.8 & 1.6 & 2.8 \\
\hline Dyna-Gro 37RY52 & 2013 & 67.4 & 48.2 & 1.8 & 1.6 & 48.2 & 48.3 & 1.8 & 2.1 \\
\hline Dyna-Gro 33C59 & 2013 & 62.5 & 40.3 & 1.8 & 2.3 & 40.3 & 65.3 & 1.5 & 2.5 \\
\hline Progeny 4949 & 2013 & 50.2 & 42.6 & 2.3 & 2.3 & 42.6 & 17.3 & 2.4 & 3.4 \\
\hline Progeny 5650 & 2013 & 87.3 & 66.8 & 1.6 & 2.3 & 66.8 & 55.8 & 1.9 & 2.1 \\
\hline Progeny 5706 & 2013 & 90.3 & 87.8 & 2.0 & 2.4 & 87.8 & 85.8 & 1.6 & 2.4 \\
\hline Terral 59R16 & 2013 & 57.0 & 55.0 & 2.6 & 2.6 & 55.0 & 55.1 & 2.3 & 3.5 \\
\hline PI 424324B & 2013 & 95.5 & 89.5 & 1.8 & 1.3 & 89.5 & 92.2 & 1.0 & 1.1 \\
\hline Osage & 2013 & 73.0 & 42.1 & 2.0 & 2.1 & 42.1 & 40.9 & 1.9 & 2.0 \\
\hline Mean & & 73.3 & 59.2 & 2.0 & 2.2 & 59.2 & 61.2 & 1.8 & 2.4 \\
\hline LSD & & 24.5 & 23.3 & 0.7 & 0.7 & 23.3 & 24.3 & 0.4 & 0.7 \\
\hline
\end{tabular}

${ }^{\mathrm{r}}$ Harvested promptly at R8 growth stage.

s Delayed harvest 2 weeks after R8.

${ }^{t}$ Percent seed germination based on tests of 100 seed from each of four replications.

u Visual seed quality were assessed using a scale of 1 to 5 .

${ }^{v}$ Noninoculated control sprayed with distilled water.

${ }^{w}$ Plants were inoculated with spore suspension of Phomopsis longicolla $\left(2 \times 10^{5} / \mathrm{ml}\right)$ at the R5 stage.

${ }^{x}$ Resistant check.

y Susceptible check.

${ }^{\mathrm{z}}$ Fisher's protected lease significant difference (LSD) test $(P \leq 0.05)$. 
south (Mayhew and Caviness 1994). In this study, we analyzed the effect of harvest times (prompt versus delayed harvest) on the incidence of PSD. Our research has demonstrated that seed infected by $P$. longicolla was more severe with delayed harvest compared with prompt harvest at maturity. Cultivars that had low Phomopsis seed infection when harvest was prompt could be susceptible to $P$. longicolla with delayed harvest. An example is Morsoy R2S 480, which had the lowest Phomopsis seed infection in the on-time harvest trial, but had the highest seed infection in the delayed harvest trial in 2012. Therefore, testing cultivars under a delayed harvest regime or under the conditions that favor PSD disease development is a useful method for identification of PSD-resistant cultivars.

Wrather et al. (2003) reported that yield losses caused by PSD varied by years. Our results are in agreement with this finding. In our study, there were significant $(P \leq 0.01)$ differences of percent seed infection by $P$. longicolla in 2012 and 2013. Overall, the incidence of PSD was higher in 2012 than that in 2013. This difference could be due to, but not limited to, the weather conditions in each year. Although the maximum air temperatures were similar during the soybean growing season in 2012 and 2013, total precipitation during August in $2012(169 \mathrm{~mm})$ was three times higher than in 2013 $(51 \mathrm{~mm})$, when most plants were at R5 growth stages when beans began to develop (Fehr and Caviness 1997). The difference in August rainfall between the two years was likely the main cause of difference in PSD incidence between the two years.

Pathogen infection is often erratic under field environments due to uneven distribution of the pathogen. Inoculation treatments have been used to increase disease pressure in field and greenhouse experiments for identification and confirmation of disease resistance in soybean (de Farias Neto et al. 2006; Hartman et al. 1997; Li et al. 2011; Mueller et al. 2003; Shakiba et al. 2012). Artificial inoculation under controlled conditions can reduce the incidence of disease escape by providing a more uniform environment for pathogen growth and disease development. In this study, regardless of maturity group harvest scheme, seeds from inoculated trials had higher incidence of PSD than noninoculated trials. However, if the weather conditions are non-conducive for PSD development, inoculation treatment may not differentiate resistant from susceptible lines. For example, in a previously published experiment in 2011, extremely hot and dry weather during late season resulted in almost no seed infection in inoculated and noninoculated trials in Arkansas, Missouri, and Mississippi (Li et al. 2015c). Moreover, if the weather conditions

Table 8. Pearson correlation coefficients between percent seed infection with Phomopsis longicolla and seed germination, and visual seed quality in replicated field tests in Stoneville, MS, in 2012 and 2013

\begin{tabular}{lclccccc}
\hline \multirow{2}{*}{$\begin{array}{l}\text { Maturity } \\
\text { group }\end{array}$} & & & \multicolumn{2}{c}{ Germination } & & \multicolumn{2}{c}{ Visual quality } \\
& Treatment $^{\mathbf{u}}$ & Harvest $^{\mathbf{v}}$ & $\boldsymbol{r}$ & $\boldsymbol{r}^{\mathbf{y}}$ & & $\boldsymbol{r}$ & $\boldsymbol{p}$ \\
\hline IV & Non & Prompt & -0.6324 & 0.1779 & & 0.1900 & 0.7184 \\
IV & Inoc & Prompt & 0.5273 & 0.2824 & & 0.0847 & 0.8732 \\
IV & Non & Delayed & 0.7835 & 0.0026 & & 0.3499 & 0.2649 \\
IV & Inoc & Delayed & -0.6111 & 0.0071 & & 0.4500 & 0.0610 \\
IV & Non & All times & -0.8784 & $<0.001$ & & 0.0332 & 0.8960 \\
IV & Inoc & All times & -0.8094 & 0.0014 & & 0.1548 & 0.6309 \\
V & Non & Prompt & -0.6149 & 0.0585 & & 0.1010 & 0.7814 \\
V & Inoc & Prompt & -0.5037 & 0.1378 & & 0.5420 & 0.1056 \\
V & Non & Delayed & -0.6533 & $<0.0001$ & & 0.1558 & 0.3371 \\
V & Inoc & Delayed & -0.7977 & 0.0057 & & 0.4381 & 0.2054 \\
V & Non & All times & -0.7479 & 0.0001 & & 0.0386 & 0.8717 \\
V & Inoc & All times & -0.6255 & 0.0032 & & 0.4439 & 0.0500 \\
\hline
\end{tabular}

${ }^{\mathrm{u}}$ Inoculation treatments. Non $=$ noninoculated control sprayed with distilled water; Inoc $=$ inoculated with spore suspension of $P$. longicolla $\left(2 \times 10^{5} / \mathrm{ml}\right)$ at the R5 growth stage.

v Prompt: harvested at R8 growth stages, delayed: harvested 2 weeks after R8.

w Percent seed germination.

$x$ Visual seed quality were assessed using a scale of 1 to 5 .

y Pearson correlation coefficients.

z Probability. are wet and humid, there was little or no significant difference between inoculated and noninoculated treatments ( $\mathrm{Li}$ et al. 2011). The quality and quantity of the pathogen inoculum must be taken into account for field screening experiments with inoculation treatments. Inoculation experiments can fail if poor quality inoculum (the pathogen is unviable or has low virulence or was not properly maintained) is used. In screening diverse soybean germplasm lines for reaction to purple seed stain (PSS) caused by Cercospora kikuchii, Alloatti et al. (2015) found that an old isolate of $C$. kikuchii with reduced sporulation likely contributed to the lower infection rate. In one of our previous field tests (unpublished data), inoculation with a spore suspension of less than $1.5 \times 10^{4} / \mathrm{ml}$ did not produce good seed infection, especially when the weather was not favorable for PSD. The use of natural infection could be an alternative approach for screening resistance to soybean diseases in the field, but the best results will only be obtained when the environmental conditions are conducive for disease development. There is often a high risk for plants escaping pathogen infection if the pathogen is not evenly distributed in the field, leading to false conclusions in identifying resistance.

Seed quality is very important for the soybean growers and processors. PSD is a soybean seed disease causing poor seed quality and reducing seed germination. In this study, susceptible cultivar AP 350 had poor germination, especially in inoculated trials with delayed harvest, while resistant genotypes, such as Morsoy R2 491, PI 424324B, and Progeny 5706 had high germination. We also found that percentages of Phomopsis seed infection were significantly $(P \leq 0.01)$ and negatively correlated with seed germination in either noninoculated or inoculated treatments with delayed harvest. However, the negative correlation between Phomopsis seed infection and germination rate was not significant in the prompt harvest trials. This is likely due to the lower seed infection rates compared with delayed harvest.

The visual seed scoring method was developed to evaluate seed quality ( $\mathrm{Li}$ et al. 2015c). Since there are different seed-borne pathogens in soybean (Baird et al. 2001; Hartman et al. 2015), seed with poor appearance could be coinfected by other pathogens besides $P$. longicolla. In this study, a number of different fungal pathogens, such as Alternaria, Cercospora, and Fusarium spp. were identified during the seed plating assays. Therefore, identification of sources of resistance to multiple seed-borne pathogens can greatly improve seed quality of soybean.

The use of PSD-resistant cultivars to protect soybean crops from the disease is economical and environmentally prudent, especially when using the popular ESPS in southern states. In this study, significant differences in seed infection among cultivars in response to $P$. longicolla attack were observed. Differences among cultivars were also reflected in seed germination and visual seed quality. Six cultivars, including one MG IV (Morsoy R2 491) and five MG V (Progeny 5650, Progeny 5706, Asgrow 5606, Asgrow 5831, and Dyna-Gro33C59), had significantly $(P \leq 0.05)$ lower seed infection than the susceptible checks and other cultivars in the same tests at both harvest regimes. The fact that group IV cultivars had more infection to Phomopsis than group V cultivars may be related to relative maturity. Information obtained from this study will be useful for soybean growers and breeders for selection of cultivars for planting or breeding and future genetic studies in the development of cultivars with improved resistance to PSD.

\section{Acknowledgments}

This research was funded by grants from the Mississippi Soybean Promotion Board, Grant \# 30-2011, 30-2012, and 30-2013, and was also partially supported by the USDA-ARS Project 6402-21220-012-00D, Crop Genetics Research Unit at Stoneville, MS. We are grateful to Ms. Avis Clark, Dr. Sciumbato's group, and numerous temporary employees for their assistance with this research.

\section{Literature Cited}

Alloatti, J., Li, S., Chen, P., Jaureguy, L., Smith, S. F., Florez-Palacios, L., Orazaly, M., and Rupe, J. 2015. Screening a diverse soybean germplasm collection for reaction to purple seed stain caused by Cercospora kikuchii. Plant Dis. 99: $1140-1146$

Association of Official Seed Analysts. 2001. Rules for testing seeds. Assoc. Official Seed Analysts, Las Cruces, NM. 
Baird, R. E., Abney, T. S., and Mullinix, B. G. 2001. Fungi associated with pods and seeds during the R6 and R8 stages of four soybean cultivars in southwestern Indiana. Phytoprotection 82:1-11.

Balducchi, A. J., and McGee, D. C. 1987. Environmental factors influencing infection of soybean seeds by Phomopsis and Diaporthe species during seed maturation. Plant Dis. 71:209-212.

Brown, E. A., Minor, H. C., and Calvert, O. H. 1987. A soybean genotype resistant to Phomopsis seed decay. Crop Sci. 27:895-898.

Carbone, I., and Kohn, L. M. 1999. A method for designing primer sets for speciation studies in filamentous ascomycetes. Mycologia 91:553-556.

Chen, P., Sneller, C. H., Mozzoni, L. A., and Rupe, J. C. 2007. Registration of 'Osage' Soybean. J. Plant Regist. 1:89-92.

Cross, C., Wrather, A., Fothergill, K., Tindall, K., Shannon, G., Li, S., Shumway, C., and Rupe, J. 2012. Effect of lactofen, azoxystrobin, and genotypes on charcoal rot, Phomopsis seed decay and pod and stem blight in soybean. Plant Dis. 96:1154-1158.

de Farias Neto, A. L., Hartman, G. L., Pedersen, W. L., Li, S., Bollero, G. A., and Diers, B. W. 2006. Irrigation and inoculation treatments that increase the severity of soybean sudden death syndrome in the field. Crop Sci. 46:2547-2554.

Fehr, W. R., and Caviness, C. E. 1997. Stages of soybean development. Iowa Agric. Exp. Stn. Spec. Rep. 80. Iowa State Univ., Ames.

Gleason, M. L., and Ferriss, R. S. 1985. Influence of soil water potential on performance of soybean seeds infected by Phomopsis sp. Phytopathology 75: 1236-1241.

Hartman, G. L., Huang, Y. H., Nelson, R. L., and Noel, G. R. 1997. Germplasm evaluation of Glycine max for resistance to Fusarium solani, the causal organism of sudden death syndrome. Plant Dis. 81:515-518.

Hartman, G. L., Rupe, J. C., Sikora, E. J., Domier, L. L., Davis, J. A., and Steffey, K. L. 2015. Compendium of Soybean Diseases and Pests, 5th Ed. APS Press, St. Paul, MN.

Heatherly, L. G. 1999. Early soybean production system (ESPS). Pages 103-118 in: Soybean Production in the Midsouth. L. G. Heatherly and H. F. Hodges, eds. CRC Press, Boca Raton, FL.

Hepperly, P. R., and Sinclair, J. B. 1978. Quality losses in Phomopsis-infected soybean seeds. Phytopathology 68:1684-1687.

Hobbs, T. W., Schmitthenner, A. F., and Kuter, G. A. 1985. A new Phomopsis species from soybean. Mycologia 77:535-544.

Jackson, E. W., Feng, C., Fenn, P., and Chen, P. 2009. Genetic mapping of resistance to Phomopsis seed decay in the soybean breeding line MO/PSD0259 (PI562694) and plant introduction 80837. J. Hered. 100:777-783.

Jackson, E. W., Fenn, P., and Chen, P. 2005. Inheritance of resistance to Phomopsis seed decay in soybean PI 80837 and MO/PSD-0259 (PI 562694). Crop Sci. 45:2400-2404.

Jardine, D. J. 1991. The Iowa soybean pod test for predicting Phomopsis seed decay in Kansas. Plant Dis. 75:523-525.

Koenning, S. R. 2010. Southern United States soybean disease loss estimate for 2009. Proceedings of the Southern Soybean Disease Workers, the 37th Annual Meeting.

Koning, G., TeKrony, D. M., and Ghabrial, S. A. 2003. Soybean seed mottling: Association with soybean mosaic virus and Phomopsis spp. seed infection. Plant Dis. 87:413-417.

Koning, G., TeKrony, D. M., Pfeiffer, T. W., and Ghabrial, S. A. 2001. Infection of soybean with soybean mosaic virus increases susceptibility to Phomopsis spp. seed infection. Crop Sci. 41:1850-1856.

Kulik, M. M., and Sinclair, J. B. 1999. Phomopsis Seed Decay. Pages 31-32 in: Compendium of Soybean Diseases. G. L. Hartman, J. B. Sinclair, and J. C. Rupe, eds. American Phytopathological Society, St. Paul, MN.

Li, S. 2011. Phomopsis seed decay of soybean. Pages 277-292 in: Soybean Molecular Aspects of Breeding. A. Sudaric, ed. Intech Publisher, Vienna, Austria.

Li, S., Bradley, C. A., Hartman, G. L., and Pedersen, W. L. 2001. First report of Phomopsis longicolla from velvetleaf causing stem lesions on inoculated soybean and velvetleaf plants. Plant Dis. 85:1031.

Li, S., and Chen, P. 2013. Resistance to Phomopsis seed decay in soybean. ISRN Agronomy 2013:738379.

Li, S., Chen, P., and Hartman, G. L. 2015a. Phomopsis Seed Decay. Pages 47-48 in: Compendium of Soybean Diseases and Pests, 5th Ed., G. L. Hartman, J. C. Rupe, E. J. Sikora, L. L. Domier, J. A. Davis, and K. L. Steffey, eds. APS Press, St. Paul, MN.
Li, S., Darwish, O., Alkharouf, N., Matthews, B., Ji, P., Domier, L. L., Zhang, N. and Bluhm, B. H. 2015b. Draft genome sequence of Phomopsis longicolla isolate MSPL 10-6. Genom. Data 3:55-56.

Li, S., and Hartman, G. L. 2003. Molecular detection of Fusarium solani f. sp. glycines in soybean roots and soil. Plant Pathol. 52:74-83.

Li, S., Hartman, G. L., and Boykin, D. 2010. Aggressiveness of Phomopsis longicolla and other Phomopsis spp. on soybean. Plant Dis. 94:1035-1040.

Li, S., Rupe, J., Chen, P., Shannon, G., Wrather, A., and Boykin, D. 2015c. Evaluation of diverse soybean germplasm for resistance to Phomopsis seed decay. Plant Dis. 99:1517-1525.

Li, S., Smith, J., and Nelson, R. 2011. Resistance to Phomopsis seed decay identified in maturity group $\mathrm{V}$ soybean plant introductions. Crop Sci. 51: 2681-2688

Littell, R., Milliken, G., Stroup, W., Wolfinger, R., and Schabenberger, O. 2006. SAS for Mixed Models. SAS Press. https://www.sas.com/apps/pubscat/ bookdetails.jsp?pc $=59882$

Mayhew, W. L., and Caviness, C. E. 1994. Seed quality and yield of early-planted, short-season soybean genotype. Agron. J. 86:16-19.

Mueller, D. S., Nelson, R. L., Hartman, G. L., and Pedersen, W. L. 2003. Response of commercially developed soybean cultivars and the ancestral soybean lines to Fusarium solani f. sp. glycines. Plant Dis. 87:827-831.

Pathan, M. S., Clark, K. M., Wrather, J. A., Sciumbato, G. L., Shannon, J. G. Nguyen, H. T., and Sleper, D. A. 2009. Registration of soybean germplasm SS93-6012 and SS93-6181 resistant to Phomopsis seed decay. J. Plant Regist. 3:91-93.

Roy, K. W., Keith, B. C., and Andrews, C. H. 1994. Resistance of hard seeded soybean lines to seed infection by Phomopsis, other fungi and soybean mosaic virus. Can. J. Plant Pathol. 16:122-128.

Rupe, J. C. 1990. Effects of temperature on the rate of infection of soybean seedlings by Phomopsis longicolla. Can. J. Plant Pathol. 12:43-47.

Rupe, J. C., and Ferriss, R. S. 1986. Effects of pod moisture on soybean seed infection by Phomopsis sp. Phytopathology 76:273-277.

Santos, J. M., Vrandecic, K., Cosic, J., Duvnjak, T., and Phillips, A. J. L. 2011. Resolving the Diaporthe species occurring on soybean in Croatia. Persoonia 27:9-19.

Shakiba, E., Chen, P., Gergerich, R., Li, S., Dombek, D., Brye, K., and Shi, A 2012. Reactions of commercial soybean cultivars from the Mid South to Soybean mosaic virus. Crop Sci. 52:1990-1997.

Sinclair, J. B. 1993. Phomopsis seed decay of soybeans - a prototype for studying seed disease. Plant Dis. 77:329-334.

Spilker, D. A., Schmitthenner, A. F., and Ellett, C. W. 1981. Effects of humidity, temperature, fertility, and cultivar on the reduction of soybean seed quality by Phomopsis sp. Phytopathology 71:1027-1029.

TeKrony, D. M., Egli, D. B., Stuckey, R. E., and Balles, J. 1983. Relationship between weather and soybean seed infection by Phomopsis sp. Phytopathology 73 914-918

TeKrony, D. M., Egli, D. B., Stuckey, R. E., and Loeffler, T. M. 1985. Effect of benomyl applications on soybean seedborne fungi, seed germination, and yield. Plant Dis. 69:763-765.

White, T. J., Bruns, T., Lee, S., and Taylor, J. W. 1990. Amplification and direct sequencing of fungal ribosomal RNA genes for phylogenetics. Pages 315-322 in: PCR Protocols: A Guide to Methods and Applications. M. A. Innis, D. H. Gelfand, J. J. Sninsky, and T. J. White, eds. Academic Press, Inc., San Diego, CA.

Wrather, J. A., and Koenning, S. R. 2009. Effects of diseases on soybean yields in the United States 1996 to 2007. Plant Health Prog. doi:10.1094/PHP-20090401-01-RS

Wrather, J. A., Shannon, J. G., Stevens, W. E., Sleper, D. A., and Arelli, A. P. 2004. Soybean cultivar and foliar fungicide effects on Phomopsis sp. seed infection. Plant Dis. 88:721-723.

Wrather, J. A., Sleper, D. A., Stevens, W. E., Shannon, J. G., and Wilson, R. F. 2003. Planting date and cultivar effects on soybean yield, seed quality, and Phomopsis sp. seed infection. Plant Dis. 87:529-532.

Xue, A. G., Morrison, M. J., Cober, E., Anderson, T. R., Rioux, S., Ablett, G. R., Rajcan, I., Hall, R., and Zhang, J. X. 2007. Frequency of isolation of species of Diaporthe and Phomopsis from soybean plants in Ontario and benefits of seed treatments. Can. J. Plant Pathol. 29:354-364.

Zimmerman, M. S., and Minor, H. C. 1993. Inheritance of Phomopsis seed decay resistance in soybean PI 417479. Crop Sci. 33:96-100. 